\title{
Itinerario de imágenes del indígena chaqueño. Del "Territorio Indio del Norte" al Territorio Nacional y Provincia del Chaco
}

\author{
Mariana Giordano \\ Instituto de Investigaciones Geohistóricas-CONICET \\ Resistencia, Argentina
}

La región chaqueña fue una de las últimas zonas del territorio argentino incorporadas a la "vida productiva nacional", luego del sometimiento armado de los grupos aborígenes que la habitaban. Este proceso, reiniciado en 1879, culminó hacia 1912 con las Campañas de pacificación, y marcó decididamente el imaginario sobre el indígena chaqueño. En este contexto, el indígena fue objeto de atención en diversos géneros discursivos, surgiendo a partir de dichos discursos imágenes complejas, cambiantes y contradictorias que pueden ser comprendidas atendiendo al contexto en que se produjeron, a las intencionalidades de sus emisores y a las posibilidades de recepción a que estaban sujetas. El presente trabajo analiza la manera en que se gestaron, transformaron y/o permanecieron a lo largo del siglo XIX y XX las imágenes sobre el indígena chaqueño, que hemos sintetizado a partir de tres esquemas de percepción de la realidad del indígena chaqueño: el civilizatorio, el integracionista y el reparacionista-reivindicatorio.

PALABRAS ClAVES: Indígena - Chaco Argentino - imaginario - discursos.

The Chaco region was one of the last zones to be incorporated to the productive national way of life after the armed submission of the aboriginal groups that had been inhabiting the area. This process, reinitiated in 1879, culminated around 1912 with the pacification campaigns and decidedly marked the imaginary about the Chaco indigenous. In this context, the aboriginal population was the object of attention in diverse discursive genders. Of those discourses surged complex, changing and contradictory images that can be understood by referring to the context in which they were produced, to the intentions of the emitters and the receptive possibilities to which they were subjected. This paper analyzes the way in which the images about the Chaco indigene were developed, transformed and remained during XIX and XX centuries, that we have synthetized using three reality perceptive schemes of the Chaco indigenous population: the scheme of civilization, the scheme of integration and the scheme of reparation/recovery.

KEYWORDS: Indigenous population - Chaco region - imaginary - discourses.

\section{Introducción}

Desde la organización institucional argentina simbolizada en la Constitución Nacional de 1854, los gobiernos nacionales llevaron adelante una política de lucha contra el indígena y defensa de las fronteras interio- 
res —en especial a partir de 1870_- acciones enmarcadas en un proceso más amplio que se orientaba a insertar a la Argentina en la expansión capitalista e integrarla al mercado mundial. La vasta región del Chaco Argentino, ${ }^{1}$ considerada el "desierto norte" fue una de las zonas a ocupar y poblar, para lo cual había que concluir con el "problema indígena": al igual que en la época colonial, cuando el "demonio" era el dueño de estas regiones, ${ }^{2}$ nos encontramos con un frente misional y un frente militar para dar "solución" a este "problema". En correspondencia con el interés estatal por el Chaco, la misma fue adquiriendo en la segunda mitad del siglo XIX su fisonomía política-institucional: en 1872 se crea la Gobernación del Chaco, dividida en 1884 en el Territorio Nacional del Chaco y el Territorio Nacional de Formosa (los Territorios nacionales constituían una especie de "estados intermedios" sujetos al gobierno nacional). ${ }^{3}$

El presente artículo pretende reconstruir las imágenes ${ }^{4}$ centrales que desde la segunda mitad del siglo XIX hasta la década de 1960 del siglo XX conformaron el imaginario sobre el indígena chaqueño. Los discursos que hemos seleccionado para su análisis se corresponden con el Chaco Austral, que en su correlato político-institucional comprendía el Territorio Nacional del Chaco y parte del de Formosa. A través del análisis de contenido de los diversos géneros discursivos que tomaron como objeto al indígena del Chaco Argentino, se procura descubrir las percepciones, valoraciones y nominaciones manifiestas en afirmaciones recurrentes que crearon una

1 Esta región integra a su vez el Gran Chaco, que abarca el oeste del Paraguay, el sur este de Bolivia y el noreste de Argentina (actuales provincias de Chaco y Formosa, sur-oeste de Salta y norte de Santa Fe). Por sus características geográficas, se le divide en tres grandes zonas: Boreal, Central y Austral.

2 Véase Trinchero, Héctor H.: Los dominios del demonio. Civilización y Barbarie en las fronteras de la Nación. El Chaco Central, Eudeba, Buenos Aires, 2000.

3 La Gobernación del Chaco comprendía originalmente el Chaco austral, central y parte del boreal, sufriendo una primera modificación con la creación de la Jefatura política entre 1874 y 1876 y una segunda al perderse una porción del Chaco boreal en el laudo arbitral con el Paraguay. Otra delimitación importante se produjo en 1884, y se debió a la división del distrito en dos Territorios Nacionales: Chaco y Formosa. Finalmente, las apetencias territoriales de provincias vecinas hicieron que el Chaco perdiera otras áreas: en 1886 se fijó el límite sur en el paralelo $28^{\circ}$ quedando para la provincia de Santa Fe el territorio que incluía las prósperas colonias de Las Toscas, Obligado, Villa Ocampo y Avellaneda. En 1902 se fijó el límite oeste, adjudicando a la provincia de Santiago del Estero una extensa región. Los límites definitivos con Salta y Santiago del Estero se cumplieron en varias etapas entre 1894 y 1914.

4 Cuando utilizamos solamente el concepto "imagen", nos estamos refiriendo tanto a imágenes mentales como iconográficas que conforman el imaginario y que se derivan de textos escritos y visuales; son captaciones articuladas en una reflexión que las sintetiza, las interpreta y les da sentido. Cuando analizamos obras de arte o fotografías nos referiremos con los conceptos "imágenes artísticas o visuales" procedentes de textos visuales. 
visión general sobre el objeto de estudio. Nos proponemos asimismo identificar los cambios en esas imágenes y su relación con las condiciones de producción, circulación y recepción de los discursos. Se pretende, consecuentemente, desentrañar el sistema de significaciones que los interlocutores fueron creando y que revelan su visión del mundo y del "otro", como así también, por refracción, una imagen de sí mismos. ${ }^{5}$

Cabe señalar que la elección de las fuentes estuvo vinculada a las fluctuaciones espaciales y político-institucionales que sufrió el espacio chaqueño, por lo cual, a medida que tratamos los discursos producidos en el siglo $\mathrm{XX}$, nos centramos en textos de procedencia territoriana y posteriormente provincial, ${ }^{6}$ comparándolos con los producidos en el ámbito metropolitano. ${ }^{7}$ Desde el punto de vista temporal, hemos considerado este análisis en la producción discursiva de mediados del siglo XIX hasta la segunda década del siglo XX, etapa que se caracterizó por el avance estatal sobre el espacio chaqueño y el sometimiento armado de los grupos indígenas; finalmente, analizamos los discursos que se sucedieron a lo largo del siglo XX hasta arribar a la década de 1960, época caracterizada por la utilización del indígena como mano de obra en la producción forestal y agrícola chaqueña, con el consecuente cambio progresivo de sus costumbres ancestrales.

5 La "otredad" o "alteridad" remite a los diferentes modos con que un grupo social califica, descalifica o visualiza a otro grupo, creando imágenes del otro que tienen como límites las autoimágenes de una identificación intragrupal (identidad). Por lo tanto, desde una perspectiva intragrupal, la identidad es una dimensión positiva que consiste en el conjunto de significados compartidos que especifican el "ser con y como" otros. Desde una perspectiva extragrupal, la identidad asume una dimensión negativa, o de alteridad, referida a los significados que otros asignan al grupo social o étnico o que el grupo de referencia asigna a los otros. Olivera y Briones señalan que en la relación interétnica los grupos humanos afectados, culturalmente definidos, “... se estructuran en torno a una idea de identidad que resulta de su autoimagen y las imágenes de otros considerados distintos. Por ende, en toda relación interétnica las partes se vinculan y definen mutuamente su posición a través del contrapeso entre las respectivas autoimágenes e imágenes de los otros. Dicho de otro modo, este juego de representaciones incide, inevitablemente, en las actitudes adoptadas por cada grupo en la interacción, las cuales se modelan recíprocamente." Olivera, M. A. y Briones, C.: "Políticas para el aborigen como espejo de relaciones interétnicas: un juegue entre "autoimágenes" e "imágenes del otro", Ponencia de las I Jornadas sobre políticas seguidas con el aborigen, Ministerio de Educación y Cultura, Buenos Aires, 1984, mimeo. Sobre este concepto, véase también Briones, C.: La alteridad del Cuarto mundo. Una deconstrucción antropológica de la diferencia, Ediciones del Sol, Buenos Aires, 1998; Amodio, Emanuele: Formas de la alteridad. Construcción y difusión de la imagen del indio americano en Europa durante el primer siglo de la conquista de América, Abya Yala, Quito, 1993.

6 En 1951, durante la Presidencia de Juan Domingo Perón, el Territorio Nacional del Chaco se transformó en Provincia Presidente Perón; con la caída de Perón del poder en 1955, la misma pasó a denominarse Provincia del Chaco.

7 Cuando nos referimos al "ámbito metropolitano" o "metrópoli porteña" hacemos alusión a los discursos que proceden de la ciudad de Buenos Aires, capital de la Argentina. 
Hemos abordado fuentes escritas que representan a diversos géneros discursivos: textos gubernamentales, informes de funcionarios, textos periodísticos, literatura varia, textos religiosos. En el caso de las fuentes visuales, proceden tanto de las artes plásticas (pinturas, esculturas y murales), como de la fotografía. ${ }^{8}$

\section{El indígena del "Territorio indio del Norte" en los géneros discursivos del siglo XIX}

La conquista espiritual y militar realizada en el siglo XVIII sobre la región chaqueña no dio resultados positivos para los actores blancos de las mismas. ${ }^{9}$ Desde el punto de vista militar los intentos de "guerra ofensiva" se transformaron en los esfuerzos por la "defensa" de las poblaciones fronterizas. Por otro lado, luego de la expulsión de los jesuitas, las misiones decayeron o desaparecieron; aquellas que sobrevivieron de manera muy frágil vieron su fin con las guerras de la independencia y los sucesivos conflictos interprovinciales en las primeras décadas del siglo XIX. Si bien es cierto que las fronteras con el indígena y la perspectiva militarizante no fueron dejadas de lado por completo desde la independencia hasta pasada la mitad del siglo XIX,${ }^{10}$ recién fue después de la organización constitucional en 1853 y particularmente a partir de la década de 1870 cuando se replanteó el tema de las distintas regiones del país aún en manos del indígena y retornó con mayor fuerza el discurso de la guerra.

8 Las fuentes visuales son consideradas y analizadas como "textos sociales", atendiendo a sus contextos de producción, circulación y recepción, realizándose asimismo un análisis iconográfico de las mismas. Nos interesa también examinar comparativamente textos escritos y visuales procedentes de un mismo observador, con el objeto de identificar el/los uso/s y el status atribuido a la imagen en el conjunto textual.

9 Sobre el discurso misionero y militar de la época colonial, véase Vitar, Beatriz: "Mansos y salvajes. Imágenes chaqueñas en el discurso colonial" y Sáinz Ollero, Héctor: "Comprensión y asimilación del otro. El reto de los chaqueños y el problema de la resistencia indígena en los textos jesuitas del siglo XVIII", ambos en del Pino, F. y Lázaro, C. (Coords.): Visión de los otros y visión de sí mismos, CSIC, Madrid, 1995, págs. 107 a 126.

10 En 1817 se produjo la expedición Bedoya al Chaco enviada desde Córdoba. Véase Bischoff, Efrain U.. Expedición de Bedoya al Chaco. Universidad Nacional de Córdoba, Facultad de Filosofía y Humanidades, Córdoba, 1954. También Arenales en 1833, al realizar la exploración para la navegación del Bermejo, hacía hincapié en el avance a través de una línea de fortines. Trinchero sostiene, por consiguiente, que desde la independencia hasta 1870 no se puede hablar de un período de "retroceso" en la consolidación de la frontera con el indio chaqueño. Trinchero, Los dominios del demonio ..., págs. 126 y ss. 
Desde los inicios de la etapa independiente, el Chaco pasó a ser considerado como un amplio espacio geográfico al norte del Río de la Plata ocupado por población indígena: el "Territorio indio del norte", para diferenciarlo de aquellas tierras al sur de Buenos Aires que también continuaban en poder del aborigen. Tal denominación fue la que el viajero y geógrafo Martín de Moussy le diera posteriormente en su Atlas publicado en 1869 , lo que nos revela la imposibilidad de separar la imagen del indígena de la visión del Chaco como espacio geográfico con caracteres particulares. Diferentes categorías de observadores, con intereses disímiles, fueron los productores de una importante narrativa escrita y visual, construyendo un imaginario de la alteridad donde se cruzan imágenes contrapuestas, complementarias, encontrándose, incluso, persistencias o reactualizaciones de imágenes procedentes del pasado colonial.

Si bien los límites cambiantes de las relaciones interétnicas y los diferentes puntos de partida en la construcción de una imagen de la alteridad influidos por concepciones ideológicas e intereses subgrupales- permitieron la aparición de visiones en ocasiones antagónicas, los discursos se unifican en la concepción decimonónica "civilización vs barbarie". ${ }^{11}$ Los diferentes emisores comparten, por otro lado, la estrategia de constituirse en legítimos transmisores de una realidad, observada o no, aunque en la mayoría de los casos acuden a estrategias de referenciación como signo de verosimilitud: se deja expresamente manifiesto que el modo de conocimiento del indio y lo que de él se dice es producto de un contacto directo con el "otro" (aprehensión del objeto por los sentidos y la razón); o bien, - como en muchos textos oficiales-, porque el emisor-locutor "conoce" otros sujetos competentes (funcionarios, inspectores, etc.) que le transmitieron una información recogida en el terreno, y por lo tanto objetiva y veraz.

\section{a) Discursos oficiales}

Cuando a mediados del siglo XIX y luego de la organización constitucional en 1853 se replanteó el tema de las distintas regiones del país aún

11 Las últimas décadas del siglo XIX marcaron una importante presencia discursiva del concepto "civilización", al que generalmente se equiparaba con el de "evolución", donde la "Nación" es el último estadio de un proceso creciente de racionalidad económica. Su importancia es decisiva en la construcción del Estado-Nación argentino, por cuanto aludía al tipo de sociedad que se pretendía crear. Halperín Donghi señala que la polaridad "civilización-barbarie" fue también un elemento vertebrador en el esfuerzo por distinguir la Argentina del resto de Latinoamérica. Halperín Donghi, Tulio: El espejo de la historia. Problemas argentinos y perspectivas latinoamericanas, Sudamericana, Buenos Aires, 1987. 
en manos del indígena, comenzó la creación de una nueva imagen del Chaco y su población indígena, en cuya conformación el Estado Nacional tuvo un papel decisivo, ya que el discurso oficial (nutrido a su vez de elementos del discurso científico y militar de la época), se convirtió en una estrategia para justificar su accionar político y militar sobre las regiones "en poder del salvaje". ${ }^{2}$ Tanto la Constitución Nacional de 1853, como gran cantidad de textos legislativos, informes gubernamentales, memorias de gobernadores, informes militares, etc., son una clara expresión de esta visión. Por otro lado, el frente misional nuevamente se hizo presente a partir de 1854 con los sacerdotes franciscanos de Propaganda Fide que desde los Conventos de San Lorenzo (en las cercanías de Rosario), La Merced (Corrientes) y San Diego (Salta) crearon misiones en distintos puntos del "Territorio indio del Norte".

¿Cuál fue la visión del Chaco que se construyó y circuló en esta época? Sin duda podríamos sintetizarla en el concepto tantas veces repetido en distintos géneros discursivos de "desierto chaqueño". El "territorio indio del norte" era, para el Estado argentino, un "desierto". ${ }^{13}$ En pocos años ese desierto fue presentado ante la sociedad argentina y ante el extranjero como la "tierra prometida", la "tierra del porvenir": grandes extensiones de suelo fértil, ríos caudalosos, vegetación exuberante serán los nuevos símbolos que

12 Cabe señalar que la ocupación militar produjo un fuerte impacto en la forma de vida y en la localización de los distintos grupos indígenas. El avance progresivo de las fronteras -desde Santa $\mathrm{Fe}$ a Santiago del Estero y desde Salta, a través del enclave de una línea de fortines-, obligó a muchas tribus a un reacomodamiento territorial, en especial aquellos grupos no reducidos. Finalizada la gran campaña ofensiva en 1884, se produjo un confinamiento en los bordes del ámbito chaqueño, con grandes grupos concentrados en el paralelo $23^{\circ} \mathrm{S}$, revelando asimismo una notable disminución de su población y dispersión de los grupos cacicales. La mayoría de los grupos se ubicaron hacia el oeste, como fue el caso de los matacos, que se convirtieron en mano de obra de los ingenios azucareros de Salta y de los obrajes madereros. Por su parte, los tobas permanecieron en sus tierras del oriente, concurriendo principalmente al ingenio de Las Palmas, a las tareas en obrajes y como mano de obra de distintas tareas rurales. En la región meridional del Chaco austral continuaron establecidos grupos de tobas y mocovíes. Véase Maeder, E. y Gutiérrez, R.: Atlas Histórico del Nordeste Argentino. IIGHI-UNNE, 1995, Resistencia, págs. 96-97.

13 Lois ha analizado la construcción discursiva del concepto "desierto chaqueño" a través de textos que circularon en la Sociedad Geográfica Argentina y en el Instituto Geográfico Argentino, como así también ciertos discursos militares, que en su conjunto sirvieron de justificación ideológica y fundamentación del accionar político de las últimas décadas del siglo XIX. Véase Lois, Carla: "La invención del desierto chaqueño. Una aproximación a las formas de apropiación simbólica de los Territorios del Chaco en los tiempos de formación y consolidación del Estado Nación Argentino”, Scripta Nova, 38, Barcelona, abril de 1999. Por su parte, Wright ha estudiado el discurso oficial del desierto y sus transformaciones a través del tiempo. Véase Wright, Pablo: "El Desierto del Chaco. Geografías de la alteridad y el estado", en Teruel, Ana y Jerez, Omar (Comps.): Pasado y presente de un mundo postergado. UNJU,UNHIR, Jujuy, 1998, págs.35-56. 
llamaban a la epopeya de inmigrantes y habitantes de regiones limítrofes. Pero para poblarlo se debía terminar con un "problema": el indígena.

En el discurso oficial, distinguimos el que procede de la legislación nacional — producido desde la metrópoli porteña-, de aquel emanado de textos de funcionarios, militares, expedicionarios que estuvieron en el Chaco. El discurso legislativo nacional se valió en muchos casos del segundo grupo de textos señalado para justificar sus afirmaciones y valoraciones, ya que no podían constatar un contacto directo con la problemática a la que se referían. El mismo se sustenta en el ideario del discurso de la guerra y pretende erigirse en depositario del colectivo de identificación nacional, ${ }^{14}$ el ver y sentir del "nosotros" frente a los "otros": para lograr la identidad nacional se debía oponer civilización=blanco $/$ barbarie=indio, como categorías antagónicas y fijas. Desde la mirada oficial nacional, se creyó que con la Campaña Victorica de 1884 se terminaba con el problema indígena y entre 1890 y 1904 se discutió principalmente en el ámbito legislativo la forma de proceder con los indios "sometidos", llamados también "indios amigos", en oposición a los "indios nómades", cuya existencia era reconocida, pero principalmente en clara oposición a los "indios de antes", es decir, a los que se opusieron en el pasado - por cierto no muy lejano- a la civilización. Las soluciones desde el discurso legislativo se contradecían: mientras algunos planteaban la exclusión total del indígena del mundo del blanco, aduciendo a fundamentos de inferioridad racial, otros se inclinaban por un mestizaje biológico a través de la absorción de la "raza inferior" a la "superior". Por otro lado, el debate sobre los sometidos se centraliza en las atribuciones de la Iglesia o el Estado para efectuar una reducción, recrudeciéndose a fines del siglo XIX el conflicto entre estos dos poderes, aunque el Estado seguía prefiriendo las misiones religiosas a las colonias agropastoriles estatales. ${ }^{15}$

En el caso del discurso producido por funcionarios que estuvieron en el Chaco, la observación directa de la problemática se convertía en garantía de la objetividad de las afirmaciones, valoraciones y percepciones.

Hasta la expedición militar al Chaco a cargo del General Victorica en 1884, el Estado Nacional se centró en la necesidad de lograr la seguridad a través de la lucha armada contra la amenaza del "salvaje". A partir de

14 Sobre la construcción del "colectivo de identificación nacional", Lenton, Diana: La imagen en el discurso oficial sobre el indígena de Pampa y Patagonia y sus variaciones a lo largo del proceso histórico de relacionamiento; 1880-1930. Tesis de licenciatura. Facultad de Filosofía y Letras, UBA, 1994. (mimeo)

15 Lenton, Diana: "La cuestión aborigen en el Congreso Nacional. 1880-1976", Revista Naya, Año II N. ${ }^{\circ} 14,1997$. Disponible en Internet: http://www.naya.org.ar/articulos/identi09.htm. 
entonces, y distinguiendo discursivamente entre "mansos/amigos/sometidos" y "salvajes/enemigos/no sometidos" la visión se renovó con los conceptos de "integración" y "asimilación", propósitos que se lograrían mediante distintas modalidades en las que los agentes del Estado - legisladores, gobernadores, inspectores, etc.- no encontraron coincidencia, pero que en la mayoría de los casos estaban relacionadas con la utilización de la mano de obra de los indígenas "amigos" y la "pacificación" de las "tribus salvajes" (que no era otra cosa que la acción militar sobre éstas), para lograr su reducción. Surgieron así dos visiones contrapuestas: aquella que presentaba al indio como un elemento que contribuiría al progreso del Chaco integrándolo a la Nación como mano de obra en haciendas, obrajes y algodonales, ${ }^{16} \mathrm{y}$ en contraposición la que negaba tal condición, insistiendo en las imágenes heredadas de épocas anteriores que encontraban en el indio el símbolo de la barbarie. Veamos la evolución de estas imágenes en diversos textos de funcionarios enviados al "desierto chaqueño".

El agrimensor Arturo Seelstrang, quien en 1875-76 dirigiera la Comisión Exploradora para la demarcación de tres colonias en el Chaco las que serían hitos de penetración y avance de la frontera-, comparaba al "salvaje" con el tigre, por el temor que despertaba, porque era el poseedor de la muerte y de la destrucción, y por su condición de "... haraganes y amantes de la libertad, desconfiados y amigos de lo ajeno, valientes y crueles hasta la bestialidad". ${ }^{17}$ Contemporáneo a Seelstrang, el gobernador Napoleón Uriburu encontraba en el indio "sometido" un elemento útil para transformar el Chaco en la tierra del porvenir. Expresaba en 1875 que “... el principal elemento que se precisa para la explotación de las abundantes riquezas naturales que contienen esos fértiles territorios, desiertos hoy casi en su totalidad, es la población...; de consiguiente no es difícil comprender cuan conveniente sería convertir a los indios salvajes, hostiles hasta ahora a toda civilización, en otros tantos colaboradores del progreso de estas comarcas". ${ }^{18}$

16 Expresa Lagos que "Detrás de este discurso subyacía en realidad el hambre de braceros y la apetencia por esta mano de obra barata. Aunque muchos de los que pensaban en el tema de la integración, estaban convencidos sinceramente de que el trabajo era el elemento integrados por excelencia, no lograban percatarse que apetencias más concretas superaban sus idealizaciones." Lagos, Marcelo: "Problemática del aborigen chaqueño. El discurso de la "integración" 1870-1920", en Teruel, A. y Jerez, O., Fronteras, ciudades y esiados, Acción, Córdoba, 2002, pág. 65. pág. 107.

17 Seelstrang, Arturo: Informe de la Comisión Exploradora del Chaco, Buenos Aires, 1878,

18 Uriburu, Napoleón: “Memoria presentada al Ministro del Interior Dr. Simón de Iriondo por el Gobernador del Chaco del 12 de septiembre de 1875", en Memorias e Informes de la Primera Gobernación del Chaco 1872-1884, Instituto de Historia, Resistencia, UNNE, 1977, pág. 147. 
Varios gobernadores del Territorio Nacional del Chaco y funcionarios como Bialet Massé, Niklison y Lynch Arribálzaga, que actuaron hacia principios del siglo XX, intentaron revertir la imagen impuesta por Seelstrang en el ámbito oficial nacional, adelantándose en la formulación de los conceptos integracionistas que recién se generalizaron en los discursos posteriores a las campañas de pacificación al Chaco. Juan Bialet Massé, que en 1904 elevó al ministro del Interior su Informe sobre el estado de las clases obreras en el interior de la República, dedica un capítulo del mismo al Territorio Nacional del Chaco. Bialet Massé retomó aquella idea del Chaco como tierra prometida que encontramos en el Informe de la Comisión Exploradora casi veinte años antes; considera al Chaco el "edén", el "paraíso", con un suelo prodigioso y único en la Argentina, ${ }^{19} \mathrm{y}$ emite juicios sobre el indígena a partir del estudio de su "psicobiología". Consideraba al indio en el conjunto de los grupos poblacionales del Chaco como un "paria", caracterizándolo como "... bueno y manso, tímido, con la timidez de tres siglos de persecución, sin el alivio de una victoria, acobardado por el continuo desastre, cazado como una fiera, y sin derecho a radicarse en ninguna parte.... ${ }^{20}$

Aunque el interés de Bialet Massé residía en informar sobre la situación del trabajador —en este caso el indígena-, realizó descripciones de la psicología, costumbres y caracteres de las distintas tribus del Chaco. Vio en el indio, como ya se venía reiterando en el discurso oficial de la época, la mano de obra más adecuada para el Chaco, considerando el trabajo el medio de integración de estas poblaciones.

Otros documentos de funcionarios que recorrieron el Chaco cuando habían culminado las campañas militares, son aquellos emanados del inspector del Departamento del Trabajo José Elías Niklison. Este funcionario realizó una inspección en 1914 en los Territorios Nacionales del Chaco y Formosa, y sus conclusiones, fruto de la "observación" - y por ello se convierten en notas "verdaderas" según sus propios conceptos-, van más allá de la tarea que le encomendaron, brindando una visión particular del Chaco y del indígena. En el libro referido a los tobas, Niklison también se ubica entre quienes vincularon la belleza y la riqueza natural del Chaco con su población indígena. En un discurso de cariz literario, este inspector men-

19 Bialet Massé, Juan: Informe sobre el Estado de las Clases Obreras en el Interior de la República, T.I, Imprenta y Editora de Adolfo Grau, Buenos Aires, 1904, pág. 29.

20 Ibídem, pág. 33. 
ciona el exotismo y la belleza del paisaje de los tobas, a lo que suma la fecundidad de las tierras, la riqueza de sus frutos y la benignidad del clima. ${ }^{21} \mathrm{Su}$ imagen del indígena chaqueño es altamente positiva, haciendo una semblanza de tinte poético del indio toba:

"Nada en sus rostros grandes y despejados, en sus ojos mansos velados de nostalgias ... ni en sus bocas dilatadas ... dice de los instintos de ferocidad y de rapiña que algunos escritores le han atribuido, con evidente ligereza... no pudieron ser ni son temibles, sino cuando atacados sin piedad en sus propios dominios por los blancos viéronse precisados a la defensa". ${ }^{22}$

Esta imagen benigna responde, sin embargo, a la concepción del indio como un niño indefenso, inocente, dócil, franco y generoso, a quien era fácil manejar. En correspondencia con este pensamiento, y haciéndose eco de conceptos vertidos anteriormente por el explorador Baldrich, Niklison dio un vuelco en las significaciones de los conceptos civilización/barbarie propios del siglo XIX, ya que la "vida primitiva, apacible y descuidada" se presenta en este discurso como un ideal al que la "civilización" contaminó a través de la pretendida integración del indio a través del trabajo. ${ }^{23}$

\section{b) El imaginario franciscano}

En el discurso misionero procedente de los frailes de Propaganda Fide se encuentran conceptos semejantes a otros géneros discursivos de la época, que conforman los puntos indiscutibles sobre la realidad chaqueña: es una región "desértica", donde la "civilización" debe realizar su labor sobre la "barbarie". Sin embargo, no hubo unanimidad de visiones acerca del indígena entre los sacerdotes, ya que para algunos la acción civilizadora era factible, mientras que para otros se presentaba como un objetivo difícil dada la percepción general que tenían de los indígenas, los que "se asemejaban a las fieras más que a los hombres”. En la Relación informativa sobre la Reducción de San Buenaventura del Monte Alto, el sacerdote anónimo que realizó la misma manifestaba:

21 Niklison, José E.: Los tobas, Jujuy, UNJ, 1990, págs. 42-43. (Reedición del original que se encuentra en el Boletín del Departamento Nacional del Trabajo, N. ${ }^{\circ} 32$. Imprenta y Encuadernación de la Policía, Buenos Aires, 1916).

22 Ibídem, págs. 42-43.

23 Ibídem, págs. 43. 
“... criados en los montes en compañía de las bestias feroces, se aproximan más a estas qe. al ser de hombre, y se pueden definir, hombres en potencia, y animales en acto..... ${ }^{24}$

Los pasos a seguir para convertir la "fiera" en "hombre" eran primero la "civilización" y después la "conversión":

\begin{abstract}
"Entidades de esta naturaleza, es necesario qe. lleguen primero a ser hombres antes que tratar de hacerlos cristianos; principiar de la educación civil, pa.qe. puedan después recibir la cristiana y religiosa; qe. aprendan a respetar las ordenes, y disposiciones de los hombres, y cumplir con ellas, para poder, y saber guardar los mandamientos, y preceptos de Dios, y temer sus castigos. En fin es necesario qe. sepan, y comprendan lo qe. es felicidad temporal, y ayudarles a alcanzarla, pa. qe. en el desarrollo de sus facultades intelectuales por medios materiales, y temporales puedan elevar la consideración, a la eterna y verdadera". ${ }^{25}$
\end{abstract}

Es así que reiniciada la tarea misional a mediados del siglo XIX a cargo de los franciscanos de Propaganda Fide, los misioneros vieron en estas tierras un lugar propicio para su labor evangélica, oponiéndose a la conquista militar y reclamando la falta de apoyo estatal para su tarea. Sus escritos tratan de introducir en la opinión pública una imagen más positiva del indígena, enfrentándose a las generalizaciones de las imágenes de la opinión pública y justificando acciones de venganza o sublevaciones ocasionadas por malos tratos por parte del blanco. Aún el Padre Gobelli — quien administró la Misión de Nueva Pompeya-, cuya visión del indígena, en especial del mataco, no fue tan positiva como el resto de los frailes, consideraba el mal trato y los abusos del blanco como causal de venganzas. En efecto, Gobelli presentó a los matacos de la siguiente forma: la tribu más degradada y la más refractaria a la civilización, caracterizada por su haraganería, estupidez, carácter reservado, abyecto, cobarde, indolente y perezoso, de entendimiento obtuso, desconfiados, inconstantes, de memoria y facultades mentales limitadas, de voluntad versátil, ociosos, vengativos, desagradecidos, borrachos y rateros. ${ }^{26}$

24 "Relación informativa sobre la Reducción de San Buenaventura sita en el parage denominaado Monte Alto en el Chaco", en Viñuales, Graciela: Nuevos aportes documentales sobre San Buenaventura del Monte Alto, Primer Encuentro de Geohistoria Regional, Corrientes, IIGHI, 1980, pág.317.

25 Ibídem.

26 Gobelli, Rafael: Estudio Etnográfico sobre los indios matacos, Imp. y Lib. Rafael I. Tula, Salta, 1914. 
Sin embargo, la generalidad de los discursos de los frailes - que trabajaron en diferentes misiones y por lo tanto con grupos étnicos distintossustentaron la idea del "buen salvaje": ello se debió a la necesidad de realizar una defensa del indígena ante una opinión pública en muchos casos adversa, como también para afianzar lo positivo de su labor civilizadoraevangelizadora. La imagen del "indio-niño" incapaz de valerse por sí mismo se perfila en el discurso misionero, dando lugar a la "prédica de la defensa" a través de un discurso proteccionista-paternalista que perduró en distintos géneros discursivos del siglo $\mathrm{XX}$, en especial en el religioso y periodístico territoriano y que supone una reactualización de imágenes coloniales creadas por el mismo Estado español desde el siglo XVI. Los frailes introducen, asimismo, el tema de la "argentinidad" del indígena, cuestión que será retomada luego de la total "pacificación" de las tribus chaqueñas en la segunda década del siglo XX.

\section{c) El periodismo y la formación de la opinión pública decimonónica sobre el indígena chaqueño}

El discurso periodístico procede fundamentalmente del ámbito metropolitano, ya que el primer periódico editado en el Territorio Nacional del Chaco, El Colono, data de 1906, del que analizaremos en este apartado solamente su postura de los primeros años de edición para abordar la evolución de su discurso en el imaginario del siglo XX, que desarrollaremos más adelante. Por su parte, el periodismo de Buenos Aires se convirtió en el interlocutor del discurso oficial y de pobladores blancos, tratando esporádicamente el tema del indígena chaqueño, a diferencia de la importancia que le diera a sus pares del sur argentino. Sustentó el discurso de la conquista, que contribuyó a la política nacional de "construcción de la nacionalidad": en el marco del discurso de la guerra, el periodismo de fines del siglo XIX alegó por la necesidad del sometimiento militar del indígena como última instancia, después de haber intentado la "seducción por la paz". Sin embargo, criticó en varias oportunidades —en especial entrando en el siglo XX - la pertinencia de la labor misional, oponiéndose a las misiones religiosas por el gasto que éstas ocasionaban al Estado, como así también por supuestas arbitrariedades en el trato a los indígenas.

Luego de que el mismo Estado hubiera declarado el triunfo sobre la "barbarie" con la Campaña Victorica de 1884 y que el periodismo se hicie- 
ra eco y hasta festejara el mismo, las Campañas que sucedieron a aquella, en especial la de Winter de 1899, fueron vistas con malos ojos por la prensa, cuestionando sus resultados y considerándola ésta el más grande de los fracasos $^{27}$ y un derroche de dinero público. ${ }^{28}$

Es importante destacar la ausencia de comentarios sobre la situación social del indígena, el tema de las tierras, etc., en el periodismo metropolitano, limitándose a reproducir cartas de oficiales y noticias sobre las operaciones militares y algunas apreciaciones sobre el trabajo aborigen. El tema indígena reaparecía ocasionalmente en la prensa cuando se enviaban nuevas fuerzas militares.

Mientras, el diario territoriano El Colono manifiesta las ambivalencias y contradicciones propias de un discurso que surge en medio de la problemática, donde las relaciones entre blancos e indígenas por la posesión de la tierra determinaban los contenidos discursivos: el "pobre salvaje" o el "menor incapaz" al que había que proteger, se transforma según las circunstancias en el "haragán", "mentiroso" que había que confinar lo más lejos posible del "blanco civilizado". En sus primeros años El Colono planteó una posición proteccionista, pero a partir de 1910 se vislumbra una postura más dura con respecto al indígena, situación que se podría comprender por la defensa que hiciera este órgano del colono blanco. Consideraba incompatible la defensa de los intereses de los "pobladores" (entiéndase, blancos) con la "protección humanitaria" del indígena, por lo que expresaba:

"El problema sigue sin resolver. Estamos hoy en el mismo lugar que estábamos al iniciar la conquista del desierto. No auspiciamos la destrucción del indígena, pero sí su alejamiento desde que se somete en apariencia para destruir a traición a los colonos trabajadores que dan la vida a la Nación. El Chaco es grande: Donde se ubicó el blanco civilizado, que se desaloje al indio haragán y busque en los bosques la presa codiciada, alejándose hacia el centro del desierto. Seamos más prácticos y menos sentimentales". ${ }^{29}$

En este párrafo se encuentran conceptos que simbolizan uno de los aspectos del imaginario colectivo sobre el indio chaqueño: si éste no se sometía voluntariamente, si no cambiaba sus costumbres y servía a la Nación, había que apartarlo, alejarlo de la civilización, confinarlo a una zona que continuaría siendo el "desierto", lo cual era considerado más humanitario que conquistarlo militarmente.

27 La Prensa, Buenos Aires, 7 de noviembre de 1899.

28 La Prensa, Buenos Aires, 29 de junio de 1900.

29 El Colono, Resistencia, 20 de julio de 1911. 


\section{d) Entre la idealización y la documentación. Representaciones visuales del siglo XIX y principios del XX}

En cuanto al discurso visual, las artes plásticas de la segunda mitad del siglo XIX y principios del XX no abordaron la figura del indio chaqueño. Las excepciones fueron aquellas representaciones idealizadas del indígena y del paisaje chaqueño que realizara el artista viajero José L. Pallière en su litografía "Tobas indios del gran Chaco" y en "Indios del Gran Chaco" (esta última litografiada a partir de una fotografía, ambas ca.1864) y las imágenes estereotipadas e idealizadas del norteamericano George Catlin. ${ }^{30}$ Sin embargo, el texto fotográfico, erigido en un texto verosimilizante conforme a la concepción que se tenía de la fotografía en esa época, se convirtió tanto en el soporte visual de escritos de funcionarios, exploradores y misioneros, como en un medio de documentación por parte de fotógrafos profesionales que por diversas razones visitaron o residieron en el Chaco ${ }^{31}$ Las fotografías de los frailes, como las imágenes que introduce Gobelli en sus textos, hacían hincapié en el ideal de conversión (representaciones de grupos de indígenas descriptos como "bautizados" ó "matrimonio cristiano") y de civilización logrados (grupos de alumnos frente a la escuela). Las panorámicas de las misiones también se orientaban a resaltar este principio civilizatorio que, desde la postura misionera, era factible de llevarse a cabo por parte de los frailes. ${ }^{32}$

También los fotógrafos profesionales recorrieron desde principios del siglo XX la región chaqueña para obtener imágenes que, en la mayoría de los casos, eran comercializadas en la Capital Federal en forma de postales. Harry G. Olds, miembro de la Sociedad Fotográfica Argentina de Aficionados, Alberto Ingimbert, Boote, Fumiére entre otros, se orientaron a retratar una raza "antes que desaparezca", acentuando el ideal exótico que garantizaba la comercialización de estas imágenes. Lograron escenificar

30 Un interesante estudio sobre Catlin se encuentra en Krebs, Edgardo C.: "George Catlin and South America: a look at his "lost" years and his paintings of Northeastern Argentina", The American Art Journal, Vol. XXII, N. 4, 1990, págs. 4-39.

31 Sobre la construcción de un imaginario visual del indígena chaqueño, véase Giordano, Mariana: "Convenciones iconográficas en la construcción de la alteridad. Fotografías del indígena del Gran Chaco", II Congreso Internacional de Teoría e Historia de las Artes-X Jornadas del CAIA: Discutir el canon. Tradiciones y valores en crisis, CAIA, Buenos Aires, 2003, págs. 147-160.

32 Ver Giordano, Mariana y Méndez, Patricia: "Justificando un proyecto. Textos y fotografías de los frailes de Propaganda Fide sobre los indios chaqueños", I Congreso Internacional de Teoría e Historia del Arte - VI Jornadas del CAIA, Buenos Aires, 2003.Versión CD rom. 
una "realidad" a través de imágenes que no representan un mundo conflictivo: fueron tomadas en una época en que todavía había campañas militares en el Chaco, pero probablemente los fotógrafos solamente recorrieron aquellas regiones "pacificadas", donde el ejército ya había avanzado y el indígena estaba sometido; de ahí que éste sea representado como resabio de un mundo pasado. Eluden el conflicto a tal punto que en una postal titulada "Tribu en armas" ${ }^{33}$ nos encontramos con un grupo de indios inmóviles, posando con arcos y flechas, mirando al espectador sin que provoquen miedo ni amenaza alguna para el blanco, más aún teniendo en cuenta que muchos de estos "guerreros indios" son nada más que niños. El primitivismo que se intentó mostrar en algunas de estas vistas fue convertido en exotismo para la mirada de muchos de estos fotógrafos, preparando las imágenes para un mercado postal donde el ideal exótico era bien vendido. ${ }^{34}$

Esta mirada amable y condescendiente hacia "lo primitivo" se basaba en una crítica hacia ciertos aspectos de la "civilización" y buscaba en los resabios de organizaciones tribales la simplicidad que la propia había perdido. Por estas razones el foco de la cámara intentaba resumir un ideal de sociedad en conjunción con la naturaleza que en la realidad no existía, pues el avance militar y la ocupación de las tierras indígenas así lo atestiguaban.

\section{Imágenes del Siglo XX. Del "salvaje indómito" al "paria en su propia tierra"}

\section{a) La mirada oficial metropolitana}

Los inicios de la segunda década del siglo XX marcaron el fin de las campañas de pacificación al Chaco ${ }^{35}$ A partir de entonces, el discurso oficial metropolitano revela la desaparición del discurso de la guerra

33 Serie Rosauer 2 (1902-1903), foto reeditada en la Serie Rosauer 4 (1904). Fotógrafo: Sociedad Fotográfica Argentina de Aficionados. Albúmina en Archivo General de la Nación (Argentina).

34 Sobre la comercialización de la imagen del indígena chaqueño, ver Giordano, Mariana y Méndez, Patricia: "Indígenas chaqueños en las imágenes de postales argentinas. Primeras décadas del Siglo XX", en Unidad y diversidad en América Latina. Conflictos y Coincidencias, III Jornadas Nacionales de Historia Argentina y Americana, Facultad de Filosofía y Letras, Universidad Católica Argentina, Buenos Aires, 2000, Tomo I, págs. 197-212.

35 Las últimas campañas fueron: entre 1907 y 1911, la del coronel O’Donnel en el centro y este de Formosa y todo el Chaco, y en 1912 la del coronel Rostagno en la parte septentrional sobre el Río Pilcomayo. 
para sostener con mayor fuerza el concepto de "integración": ${ }^{36}$ en la construcción de la "argentinidad" se aceptaba la inclusión del indio, y por ello había que reparar el daño realizado, integrándolo a través de la tierra, del mercado laboral y protegiéndolo de los abusos y de su situación social y sanitaria a través de instituciones protectoras. La creación de las reducciones indígenas -en 1911 se crea Napalpí en el Territorio Nacional del Chaco y en 1914 Bartolomé de las Casas en el Territorio Nacional de Formosa - y la conformación de la Comisión Honoraria de Indios respondían a esta nueva visión que se comenzaba a consolidar. Durante los gobiernos radicales (1916-1930), el Estado Nacional recurrió en especial al concepto de "reparación histórica y cultural" atendiendo también a la situación de la salubridad del indígena y planteándose una política tutelar a través de dos tipos de acciones específicas: la "reparación", que estaba vinculada a la entrega de tierras, y la situación social y sanitaria, a la creación de instituciones de protección y asistencia. Sobre el primer aspecto, por decreto del 18 de febrero de 1924 se constituyó una reserva aborigen de 150.000 hectáreas en la zona del Río Teuco. En relación a la fundación de instituciones protectoras, en 1916 se creó la Comisión Honoraria de Indios para centralizar todas las cuestiones de "... reducción, protección y civilización de los indígenas". ${ }^{37}$ A la vez que se acentuaba la política proteccionista, se reconocía la posibilidad de progreso personal y comunal, que incluía la adquisición de derechos políticos.

La década del treinta marcó una situación particular de la población indígena chaqueña: se logró su sedentarización en reservas, la aceptación forzosa de la agricultura (la reducción de Napalpí se convirtió hacia mediados de esta década en una colonia exclusivamente agrícola) y la incorporación de los indígenas como mano de obra asalariada de las explotaciones de los blancos. Ninguno de estos aspectos se reflejó en el discurso oficial metropolitano de entonces, donde los mensajes presidenciales se limitaban a breves referencias sobre la marcha de las reducciones de Napalpí y Las Casas, la capacidad y buen desempeño de los indios como agricultores y la política educativa llevada a cabo por el gobierno nacional tanto para indios

36 Sobre los alcances de este concepto y su aplicación al caso chaqueño, véase Lagos, Marcelo: "Problemática del aborigen chaqueño, págs. 57-101.

37 Decreto del 21/IX/191, en Congreso de la Nación. Dirección de información parlamentaria: Tratamiento de la cuestión indígena, Serie Estudios e Investigaciones N. ${ }^{\circ}$ 2, Buenos Aires, 1985, págs. 94-95. 
reducidos como para aquellos que aún vivían en "estado salvaje". ${ }^{38}$ En el ámbito legislativo, tanto como en el ejecutivo, se evidencia una pérdida de interés sobre el indígena, notoria en la escasez de menciones en las fuentes hacia estos grupos y su problemática, situación que continuará en la primera mitad de la década del ' 40.

Se enviaron, sin embargo, distintos funcionarios y científicos por parte de organismos nacionales a las reducciones civiles y centros laborales de indígenas, que dejaron como consecuencia varios documentos cuyo discurso muestra las preocupaciones de los "especialistas" en la cuestión. Sobresalen, en este sentido, los informes de Lorenzo Galíndez, Arturo Ameghino y Ramón Pardal realizados para la Comisión Honoraria de Indios en 1936.

Ameghino, que informó sobre el psiquismo de los aborígenes tobas, mocovíes, vilelas, matacos, pilagás y chiriguanos, desprendió sus fundamentos científicos de una visión del indio que, según sus propias palabras, constituía un "modo de ver" esa realidad. Diferenció entre indios "libres" o "independientes" (los "ariscos" de otros discursos) y "reducidos" o "sometidos", afirmando que "... los primeros (los libres) se dejan llevar por el instinto; los otros proceden según se lo sugiere la razón.” A partir de esta afirmación, considera el afán de progreso de los indios sometidos. ${ }^{39}$

Al igual que Ameghino, Lorenzo Domínguez enfatizó en su discurso las ventajas en las condiciones de vida, salud, educación, etc. de los indios reducidos o sometidos por oposición a los salvajes, lo cual se habría logrado gracias a la tutela del Estado. Refiriéndose al beneficio material y espiritual que el régimen de colonias significó para los indígenas, señalaba que:

"En ellas el indio protegido económicamente y orientado moral y espiritualmente, trabaja en paz y ha cambiado su tipo de patrimonio cultural, ha modificado su standard de vida material y de confort, abandona sus viejos conceptos espirituales, ritos y supersticiones en lo que tienen de antisociales o de inadaptación a la colectividad nacional argentina y aprende a valorar la costumbre de la previsión económica...". ${ }^{40}$

38 Mensajes del Presidente Agustín P. Justo de 1934, 1935, 1936 y 1937, en Dirección de Información Parlamentaria: Tratamiento..., págs. 128-129.

39 Ameghino, Arturo: "Observaciones sobre el psiquismo de los aborígenes", en Ministerio del Interior. Comisión Honoraria de Reducciones de Indios: Publicación N. ${ }^{\circ} 4$, La Prensa Médica Argentina, Buenos Aires, 1936, pág. 16.

40 Galíndez, Lorenzo: "Observaciones recogidas en el Norte Argentino", en Ministerio del Interior, Publicación N. ${ }^{\circ}$....., pág. 39. 
Subyace en este discurso la idea de indio-niño, el desamparado que necesita ayuda por parte del Estado y la sociedad.

Durante la época peronista ${ }^{41}$ (1945-1955), el discurso revela la actitud paternalista del Estado que consideraba al indígena parte del "pueblo", de la "nación", y que asumía el deber de "otorgar" y "dar". Entre las nominaciones sobre el indígena en los discursos de la época eran frecuentes los conceptos de "hermano indígena" y "auténticos dueños de las tierras"; se acudía generalmente a un pasado lejano para resaltar sus valores y se exaltaba la necesidad del "resurgimiento de la raza autóctona", aspecto este último que, desde esta postura, se estaba logrando merced a la obra protectora del justicialismo. Las contradicciones discursivas son muy frecuentes en los debates legislativos de la época: mientras se los consideraba los "auténticos propietarios de las tierras", por otro lado se exclamaba la necesidad de "darles tierras" como un acto solidario y no como un legítimo derecho.

En ocasión del tratamiento en la Cámara de Senadores de un proyecto sobre la creación de escuelas granjas aparecen repetidamente los conceptos de "dar tierras", "dar escuelas", como una obligación del Estado peronista, porque estas tierras eran de los "argentinos". El senador Xamena exclamaba que "... el justicialismo sacó al indio de su agonía para hacerlo hermano nuestro y seguirá bregando para que estos aborígenes vivan y prosperen, y así tengamos siempre muestras de esa raza fuerte que un día fueron dueños de todas estas tierras de los argentinos". ${ }^{42}$

\section{b) La mirada oficial territoriana}

En la primera década del siglo comienza a perfilarse una figura de importante influencia en la cuestión indígena chaqueña: Enrique Lynch Arribálzaga, ${ }^{43}$ quien en sus Informes sobre la Reducción de Napalpí trató el trabajo y la educación como los dos pilares que permitirían la "incorporación" del aborigen a la "vida civilizada". A partir de una concepción paternalista y proteccionista respecto del aborigen y de su visión del "indio-

41 Gobierno de Juan Domingo Perón, líder del Movimiento Nacional Justicialista (por lo que en ocasiones nos referiremos a este gobierno como "peronismo" o "justicialismo").

42 Diario de Sesiones de la Cámara de Senadores del 29 de septiembre de 1953, Buenos Aires, T. II, 1953, pág. 1114.

43 Lynch Arribálzaga, gestor de la Reducción de Napalpí. Fue nombrado delegado del Ministerio del Interior en dicha Reducción y sus Informes responden a tal condición. 
niño", consideró al trabajo el medio eficaz para la erradicación del indígena, y abordó especialmente las condiciones laborales en las que aquel se debía desempeñar para evitar los abusos y la explotación. Bregó por la libertad laboral y la justa remuneración (que evitaría la desconfianza que sentían ante sus patrones), la entrega de créditos flexibles y la capitalización de sus ganancias a ser utilizadas en la construcción de buenos ranchos, adquisición de ganado y herramientas para labranza ${ }^{44}$ En su afán por comprender la cultura aborigen respecto al trabajo, Lynch Arribálzaga reconocía que la constancia en el trabajo del indio no era ejemplar, pero justificaba este comportamiento en antiguos hábitos que lo inclinaban a la caza y la pesca, como también al “... desengaño que recibe al ver constantemente burlados sus esfuerzos, que se pagan con compensaciones irrisorias. Entonces, quema los toldos y se aleja en silencio, mas no sin haber saldado antes las deudas de todos los individuos de la tribu" ${ }^{45}$ Consideraba que a través de la educación se podría lograr que, a largo plazo, se advirtiera más regularidad en el trabajo, pero para ello había que motivarlo y tratarlo de una manera especial:

“... tratándolo con afecto paternal, atendiéndolo en sus ingenuos deseos, amparándolo contra la violencia o el engaño de los mal intencionados y especialmente mostrándoles sincero interés por sus hijos; todos estos servicios y muestras de amistad lo obligan y lo atraen hacia su patrón, en quien ve entonces un protector, de que tanto necesitan su desvalimiento e ignorancia". ${ }^{46}$

Sin embargo, otra arista del discurso oficial territoriano de las décadas del '20 y '30 se esforzó por resaltar el progreso del Chaco, para el que no se contaba con el indígena. Se intentaba desterrar el símbolo de primitivismo y de tierra peligrosa representado en el indio, razón por la cual se siguieron dos estrategias discursivas: no mencionarlo en los discursos, o considerarlo como al "otro" lejano que continuaba con sus costumbres ancestrales, las que eran valoradas en forma negativa.

Como en épocas anteriores, podemos nuevamente relacionar espacio geográfico y temática indígena: en esta oportunidad por la ausencia del

44 Lynch Arribálzaga, Enrique: "Sobre la Reducción y Civilización de los Indios del Chaco y Formosa”, Estampa Chaqueña, Resistencia, 13 de julio de 1935, Año IV, N. ${ }^{\circ}$ 288, pág. 41. Este trabajo fue escrito en 1911 por Lynch Arribálzaga en concepto de un Informe elevado al ministro de Agricultura de la Nación Dr. Eliodoro Lobos.

45 Lynch Arribálzaga, Enrique: Informe sobre la Reducción de Indios de Napalpí elevado a la Dirección General del Ministerio del Interior, Imprenta de la Policía, Buenos Aires, 1914, pág.16.

46 Ibídem. 
indio en los discursos territorianos, ya que la imagen del Chaco que se pretendía consolidar se debía apoyar en quien era considerado el elemento progresista de estas regiones: el colono inmigrante, que en forma masiva comenzó a poblar las tierras "pacificadas".

Las publicaciones oficiales del entonces Territorio Nacional del Chaco, muchas de ellas realizadas para presentar el mismo al resto del país, sintetizaron distintas nominaciones que conformaban el imaginario de la época. Las imágenes resultantes de estos textos producidos entre 1930 y 1945 se pueden agrupar de la siguiente manera:

- El indio es corrupto. La corrupción estaba vinculada a determinados hábitos sociales y familiares y en algunos textos la misma se asimila a la idea de "salvaje".

De acuerdo a esta visión, El Chaco Album Gráfico Descriptivo de 1935, realizado para promocionar el Territorio en el ámbito nacional, expresaba que “... desgraciadamente ... los indios que moran en tan bellos lugares, son en extremo corruptos, resintiéndose de los instintos de los animales en medio de los cuales viven". ${ }^{47}$ También señalaba la poligamia y el mal trato a la mujer como otros indicadores de este estado de corrupción.

- El indio es haragán. Con tal nominación subtitulaba el Padre Antonio de J. Pou en el mencionado Álbum su artículo sobre los Datos Etnológicos del indio chaqueño: “... el indio es haragán e inconstante, trabaja poco y poco le importa abandonar y aún perder el fruto de sus fatigas... Verdaderamente, da grima, ver a tantos jóvenes forzudos atacados por el microbio de la ociosidad, de la haraganería". ${ }^{8}$

- El indio es sucio. La suciedad estaba relacionada discursivamente con la fealdad. El Chaco Album Gráfico Descriptivo distinguía la belleza y pulcritud de la naturaleza en oposición al descuido personal y la suciedad en que vivían los indígenas: “... el indio es muy sucio en su cuerpo, en sus vestidos (el que los tiene), en sus chozas y en sus tolderías, un tufillo molesto se desprende de su cutis sudado y barroso...". ${ }^{49}$

- El indio es víctima. Sometimiento, explotación, abusos, malos tratos, precariedad, son algunos actos nominativos que aparecen como con-

47 Gobierno del Territorio Nacional del Chaco: El Chaco. Album Gráfico Descriptivo. Buenos Aires, Compañía Impresora Argentina S. A., 1935, pág. 100.

48 Ibídem.

49 Ibídem. 
trapartida de la imagen del indio salvaje y agresor que se tuvo antes de las campañas militares al Chaco y durante los levantamientos aborígenes de la década del veinte. La "injusticia" comienza a ser un concepto frecuente tanto en informes gubernamentales, como en artículos periodísticos y discursos científicos. Este discurso está reflejando un sentimiento de culpa que se acentuó a partir de la década del ' 30 en parte de la sociedad chaqueña, cuando la problemática socio-económica del indio se hacía cada vez más evidente en los mismos centros poblados a los que acudían; por ello, surgieron en distintos ámbitos consideraciones solidarias para con el "pobre indígena." Esta imagen será central en las décadas del '40 y '50 en el discurso indigenista.

El Chaco se transformó en Provincia en 1951, durante el gobierno peronista, por lo cual es importante considerar las nominaciones de los distintos textos provinciales que, por otra parte, se correspondían con el discurso peronista metropolitano. Estas nominaciones se nuclearon en torno al concepto de "hermanos indios", a quienes se debía ayudar solidariamente para concluir con su problemática. Se continuaba con un paternalismo muy evidente, que en la práctica se manifestó en acciones humanitarias de entrega de implementos agrícolas, semillas, etc. El discurso territoriano acompañó las expresiones del Segundo Plan Quinquenal peronista (1953-57), que señalaba como un objetivo de la Acción Social estatal la "Protección del Aborigen", a través de su "incorporación progresiva" al ritmo y nivel de vida de la Nación..$^{50}$

Distintas disposiciones legales de la década del '50, ya sean pertenecientes al gobierno peronista como a las intervenciones militares, revelaron el mismo discurso, con repeticiones de conceptos que se mantenían en la sociedad chaqueña desde décadas anteriores. La normativa tuvo, por lo general, el objetivo de crear instituciones de "protección" al aborigen, y surgió en una época donde las corrientes indigenistas ${ }^{51}$ tuvieron cierto peso en el ámbito político-institucional chaqueño, de ahí que muchos de los conceptos utilizados representaran a aquellas posiciones.

El tema aborigen tuvo en el ámbito provincial un punto de inflexión en los debates previos a la sanción de la Constitución Provincial del Chaco

50 Ley N. ${ }^{\circ} 14184$. Segundo Plan Quinquenal.

51 La influencia de las corrientes indigenistas en el Chaco ha sido tratada en Giordano, Mariana: "El indigenismo chaqueño. Una propuesta alternativa a la problemática aborigen", $X X$ Encuentro de Geohistoria Regional, IIGHI-CONICET, Resistencia, 2000, T. I, págs. 411-432. 
de 1957. Los proyectos presentados por los diversos partidos políticos contemplaban distintos aspectos a tener en cuenta sobre el aborigen, entre ellos la supresión de misiones o reducciones, el reconocimiento y reivindicación de su cultura, la devolución de las "tierras usurpadas", la particular atención que se debía prestar a su educación, etc. En resumen: tierras, educación, asistencia social y costumbres fueron los temas principales presentados por los distintos Proyectos. El discurso de los mismos en muchos casos está teñido de las ideas reivindicatorias del indigenismo, que tenía gran fuerza en esta época en la Provincia del Chaco.

La Comisión Redactora de la Convención Constituyente estableció un artículo especial para el tema "Aborígenes", —el que finalmente se aprobó-, pero los debates que precedieron a su aprobación desnudan la existencia del problema indígena que en muchas oportunidades se había dado por concluido, a la vez que el discurso de los convencionales simboliza el imaginario social chaqueño sobre el indígena al arribar a los portales de la década de 1960.

El artículo 34 de la Constitución Provincial de 1957 expresa:

"La Provincia protegerá al aborigen por medio de una legislación adecuada que conduzca a su integración en la vida nacional y provincial, a su radicación en la tierra, a su elevación económica, a su educación y a crear la conciencia de sus derechos, deberes, dignidad y posibilidades emergentes de su condición de ciudadano. Quedan suprimidos los sistemas de misiones, reducciones u otros que entrañen su diferenciación y aislamiento social". ${ }^{52}$

En relación a este artículo, cabe señalar que en primer lugar se puso en discusión la pertinencia de incluir disposiciones especiales sobre el aborigen en el texto constitucional. El convencional Maldonado se oponía a tal inclusión esgrimiendo dos motivos: el primero se fundaba en que ello era contrario a la norma constitucional referida a la igualdad ante la ley, por lo que se consagraba legalmente una diferencia que — si bien no había sido la intención-, dejaba implícita una disminución jurídica y social para con el aborigen. El segundo motivo de oposición a este artículo se refería a la negativa de dejar sentada la supresión del sistema de misiones, por considerarla una cláusula discriminatoria que atentaba a la libertad.

52 Honorable Convención Constituyente de la Provincia del Chaco: Diario de Sesiones, Sesión del 1 de marzo de 1958, pág. 26. 
Por el contrario, quienes apoyaban la cláusula constitucional, entre los que se encontraba el convencional Vargas, afirmaban que con este artículo se pretendía proteger al indígena, porque es un “... ciudadano argentino y más quizá que todos, porque es el dueño primitivo de la tierra, a quien la civilización, por un fenómeno que nadie es culpable, al dueño inicial y sagrado de la tierra, en nombre de la civilización se lo va acorralando...". ${ }^{53}$ Fundaba la necesidad de este artículo en la protección que el Estado debía brindar a los aborígenes, quienes eran considerados “...extranjeros en su propia tierra ... son una raza vencida, tienen una psicología distinta". ${ }^{54}$

Estas discusiones reflejan imágenes que ya existían un siglo atrás, cuando también se mencionaba al indio como el "dueño primitivo de la tierra", sumándose en esta oportunidad otras nominaciones tales como "ciudadano argentino", "ciudadanos pacíficos y laboriosos", "extranjeros en su propia tierra", "raza vencida" a la que es necesario proteger y reivindicar. Este discurso revela, sin embargo, contradicciones muy evidentes: por un lado, se declamaba la necesidad de proteger al aborigen a través de una cláusula específica, pero por otro, el mismo convencional Vargas fundamentaba la prohibición del sistema de reducciones y misiones por ser es un "sistema de aislamiento, diferenciación y paternalismo". Es decir, había que dejarlo libre, pero a la vez había que protegerlo, no solamente para asegurar su bienestar, sino también para saldar culpas históricas.

La solución integral al problema indígena se daría, según esta perspectiva, a través de la educación, ya que “... cuando el indio aprenda un oficio ese indio será un ciudadano más como cualquier habitante de esta provincia, y eso es a lo que nosotros tendremos que llegar por medio de la educación del aborigen". ${ }^{55}$

\section{c) El periodismo y el indio en el siglo $X X$ : del "salvaje alzado" a la "raza humillada"}

En lo referente al discurso periodístico ${ }^{56}$ distinguimos las imágenes atendiendo a un hito en el proceso histórico chaqueño: la llamada

53 Honorable Convención Constituyente de la Provincia del Chaco: Diario de Sesiones, Sesión del 31 de noviembre de 1957, pág. 26.

54 Ibídem.

55 Ibídem, pág. 30.

56 Véase un análisis más detallado del discurso periodístico en Giordano, Mariana: "El indio chaqueño en el discurso periodístico", XXI Encuentro de Geohistoria Regional, Universidad Nacional de Formosa, 2001, págs. 122-130. 
"Sublevación de la Reducción indígena de Napalpí"s7 de 1924. Con anterioridad a Napalpí y en forma contemporánea a la supuesta sublevación, el manejo discursivo de periódicos territorianos y metropolitanos es claramente representativo del imaginario de la época. En momentos de los supuestos "alzamientos" del Chaco salteño inmediatamente anteriores a Napalpí, el periódico territoriano El Colono continuaba con una posición contradictoria acerca de las posibles "soluciones" al problema indígena, que iban desde la declamación de su protección hasta la necesidad de otorgarles tierras bien alejados del blanco.

Por su parte, La Voz del Chaco, periódico que apareció en 1915, se erigió en sus orígenes en el "defensor" del indio, pero su discurso comenzó a tomar un cariz diferente en los sucesos previos a la sublevación de Napalpí, al oponer conceptualmente los "chaqueños/colonos/civilizados/ nativos" a "indios/salvajes/alzados", sosteniendo a su vez la legitimidad de los reclamos de los primeros sobre los segundos, ya que en el conflicto estaba implícito el tema de la posesión de la tierra. En contrapartida, otro periódico local, el Heraldo Chaqueño ${ }^{58}$ insistía en que el discurso de $L a$ Voz del Chaco y de otros diarios de Capital Federal, acentuaba la imagen del malón, ya que las nominaciones incluían conceptos tales como el "elemento indígena", "indios ebrios", "indios chacareros y paisanos", "caciquillos taimados y ocultos". Desde entonces y en medio de los sucesos de Napalpí, "malón indígena", "vandalismo indígena", "indios levantiscos", "indios maleantes y pendencieros", fueron conceptos corrientes en los distintos artículos de La Voz del Chaco. Los mismos titulares de los diarios no sólo confundían a la opinión pública, sino que hicieron reaparecer una imagen del salvaje que parecía haber concluido con las "campañas de pacificación de la década de 1910.

57 En esta Reducción creada en 1911 a instancias de las propuestas de Enrique Lynch Arribálzaga, los indígenas se dedicaban a la explotación forestal principalmente, aunque algunos eran ocupados como peones de la administración y en trabajos agrícolas. La Rebelión de Napalpí en 1924, fue reprimida duramente por fuerzas policiales, alcanzando este hecho gran repercusión en el ámbito territoriano y nacional, y convirtiéndose en un hito en el proceso histórico chaqueño. A partir de entonces Napalpí se orientó principalmente a la explotación agrícola y sus habitantes eran clasificados en colonos y pobladores.

58 El Heraldo Chaqueño, llamado desde 1925 Heraldo del Norte, de tendencia socialista, se había comenzado a editar desde 1917 en Resistencia; no se conservan números del mismo, a excepción de una edición especial de 1925 publicada en Corrientes (por las continuas persecuciones que sufrió este diario) y dedicada exclusivamente a Napalpí, que se halla en el Archivo Histórico de la Provincia del Chaco. 
Investigaciones científicas posteriores han encontrado en Napalpí un movimiento de tipo milenarista, habiendo influido en esta Rebelión, Movimiento o Concentración — como se la llamara indistintamente-, una variedad de causas, entre ellas las diferencias políticas entre el gobernador del Territorio Nacional del Chaco y la Comisión Honoraria de Indios; la prohibición que hiciera el gobernador para que los indios se trasladasen a trabajar en los ingenios de Salta y Jujuy ${ }^{59}$-medida que fue aprobada por La Voz del Chaco y considerada como una situación de esclavitud por el Heraldo -; el maltrato de que fueron víctimas los indígenas por parte de administradores de la Reducción, sumado al descuento de un 15\% del producto de la cosecha de los indígenas (lo que no ocurría con los colonos blancos); la persecución y abuso de la policía local; y el florecimiento de prácticas y creencias fuertemente ligadas al shamanismo tradicional sobre el que se estructuró la ideología mesiánica ${ }^{60}$ del Movimiento de Napalpí.

En el discurso periodístico post Napalpí (década del '30), la problemática indígena no tuvo gran presencia pero, sin embargo, marcó el inicio de una defensa conjunta de su situación en distintos medios periodísticos, fundado en un sentimiento de culpa. El "salvaje indómito" de fines del siglo XIX y principios del XX, el "vándalo" de Napalpí, se convirtió en el "paria en su propia tierra", en la "raza humillada", en la "colectividad india". Esta última valoración la encontramos por primera vez en la Revista Estampa Chaqueña, que justificaba la utilización de este concepto:

“... porque verdaderamente los indios constituyen en la República Argentina un lamentable grupo desvinculado de la nacionalidad, quizás el más extranjero y el único absolutamente huérfano de la atención oficial y del esfuerzo o simpatía privados,

59 Los productores algodoneros de la zona de Napalpí se quejaban continuamente de la falta de mano de obra para la cosecha algodonera. Colonos blancos de Sáenz Peña habían enviado un telegrama al Ministerio de Agricultura de la Nación solicitando “... vuestra intervención ante amenaza de verdadero desastre que significa falta de brazos. Deteniendo salida de indios y haciendo regresar a los que ya llevaron, hábrase puesto un gran remedio a este mal”. En: Heraldo del Norte, 27 de junio de 1925 .

60 Los líderes mesiánicos del Movimiento fueron Pedro Maidana, José Machado, Dionisio Gómez y Pedro Gómez que, con algunas diferencias, coincidían en el uso de poderes mágicos para conversar con el espíritu de los muertos y para la cura de los enfermos. A Dionisio Gómez se le reconocía la capacidad de profetizar sobre el sentido del futuro, paliar o redimir las miserias físicas y espirituales de los indígenas, y la capacidad para comunicarse con las potencias superiores e inferiores que, según la cosmovisión toba, regulan la suerte del orden terrestre. Véase en Cordeu, Edgardo y Siffredi, Alejandra: De la algarroba al algodón. Movimientos milenaristas del Chaco Argentino, Juárez Editor, Buenos Aires, 1971, págs. 62-67. También véase en Miller, Elmer: Los tobas argentinos. Armonía y disonancia de una sociedad, México, Siglo XXI, 1979. 
comparando la realidad de su escaso amparo e indudable agonía, con los merecimientos o superación a que fueron acreedores". ${ }^{61}$

Por último, el discurso periodístico indigenista ${ }^{62}$ se enmarca dentro del accionar del grupo indigenista local y se manifestó tanto en órganos de antigua circulación en el Chaco como en nuevos órganos que los mismos indigenistas crearon. Es un discurso de reparación y reivindicación que se hizo presente en la década del ' 40 y alcanzó mucha fuerza hacia fines de los '50. El surgimiento de órganos periodísticos indigenistas en el interior del Chaco y la labor de Lázaro Flury y Juan Martín Cerdá Castillo fueron cruciales para la difusión del indigenismo y, en particular, para el surgimiento de un periodismo indigenista. Periódicos como El Vidente y La Gaceta (en la localidad de Villa Ángela) y Reivindicación (en Resistencia), postularon un discurso que navegaba entre dos vertientes: por un lado bregaba por la reivindicación del indio, contemplando la libre determinación de las distintas comunidades alejadas del tutelaje estatal, pero por otro lado hacía hincapié en la tarea solidaria y comprometida - del blanco - para con el indio, que no era sino otra forma de tutelaje. Se resaltaba, asimismo, que la "civilización", en lugar de favorecer la situación del aborigen, se había valido de él, explotándolo y destruyéndolo. En contrapartida, los emisores de estos discursos asumían que ellos - los blancosno presentaban los caracteres atribuidos al otro, pero que eran quienes tenían la "misión" de resaltar los valores y luchar por los deberes de ese otro.

\section{d) Lo "otro" y lo "autóctono" en el discurso visual}

En el discurso visual del siglo XX nos encontramos con la primera generación de artistas chaqueños que, como representantes de un sentimiento nacionalista, o con la intención de idealizar lo autóctono o de documentar tipos sociales, tomaron al indígena como objeto de sus representaciones ${ }^{63}$ El pasado del indígena chaqueño es representado a través de la bravura y valentía de una raza en el relieve escultórico La raza madre, de

61 Estampa Chaqueña, Resistencia, Año VIII, N. ${ }^{o}$ 387, 7 de agosto de 1937.

62 Giordano: "El indigenismo chaqueño ...", pág. 422.

63 Un análisis más detallado del discurso visual sobre el indígena chaqueño se encuentra en Giordano, Mariana: "Epopeya y relidad. La figura del indígena en las artes plásticas chaqueñas", XXII Encuentro de Geohistoria Regional, IIGHI-CONICET, 2003, págs. 238-247. 
Julio César Vergottini. El presente es simbolizado a través de lo autóctono en las esculturas de Crisanto Domínguez y Carlos Schenone y en los carbones del español Ramón Subirats. Una tercera visión, desde una actitud más crítica, es la que muestra al indio derrotado, no sólo a través de las armas, sino como resultado del proceso de asimilación del que estaba siendo objeto; esta imagen es visible en las tallas de Juan de Dios Mena y los óleos de Rafael Galíndez.

Por consiguiente, las imágenes de indígenas representadas por los primeros artistas chaqueños o que residieron en el Chaco entre las décadas del '30 al '60, se debaten entre representaciones de un pasado mítico y las que se inclinan por reflejar la realidad presente, desde una perspectiva costumbrista o crítica. Sin embargo, resulta sumamente significativa la ausencia de valoraciones negativas, aspecto que se puede vislumbrar en otros géneros discursivos de la misma época. Por otro lado, en el contexto del arte indigenista americano, la producción artística chaqueña navega entra dos vertientes de representación del indígena, la crítica y la estética, sin identificarse plenamente con ninguna de ellas.

Hacia fines de los años '50 advertimos la influencia del indigenismo en algunos artistas de localidades del interior chaqueño que, a través del retrato, pretendieron reivindicar una raza: Menoldo Díaz es probablemente el mayor representante de esta corriente indigenista en el arte, cuya producción, caracterizada por un realismo fotográfico, continúa hasta la actualidad. Sin embargo, en los inicios de los '60, la temática indígena decayó en el campo artístico chaqueño, consecuente con la escasa aparición de la problemática en otros géneros discursivos.

En el caso de la fotografía, también centramos nuestro análisis en aquellas obtenidas por chaqueños o por funcionarios que documentaron sus escritos a través del texto fotográfico. Es así que la fotografía del siglo XX, por un lado, sirvió de soporte ilustrativo al periodismo chaqueño, pero también fue el medio de documentación científica (numerosos antropólogos recorrieron el Chaco para estudiar su población aborigen), documentación de funcionarios y viajeros, para llegar a los años cincuenta con la presencia de la fotografía artística en la representación del indígena chaqueño.

El periodismo y las publicaciones oficiales utilizaron la fotografía como un modo de documentar los éxitos de la integración del indígena. La publicación oficial El Chaco. Álbum Gráfico Descriptivo presenta en el discurso escrito una imagen negativa de las costumbres indígenas, mientras el texto fotográfico rescata esas costumbres como ejemplo de "lo 
autóctono": la venta de alfarería, hierbas y pájaros realizadas por mujeres indias, o la costumbre de beber en la selva el cardo caraguatá son ejemplos de una cultura a la que, desde la imagen visual, se trata en forma condescendiente.

Por otro lado, la documentación de costumbres, situación social y grado de aculturación logrado por el blanco, fueron otros de los aspectos representados por la fotografía que, en la década del '60, incorpora al blanco junto al indio, para mostrar así las acciones solidarias que llevaba a cabo.

Las imágenes obtenidas por fotógrafos profesionales manifiestan un fuerte cariz documental, como el trabajo que Grete Stern realizara en el Gran Chaco entre 1958-60 y 1964, con tomas de gran contundencia, caracterizadas por un realismo que traduce una cierta concepción de la realidad del indígena, de su relación con la naturaleza, de sus costumbres, pero también un compromiso personal de la autora por hacer conocer a los blancos las condiciones de marginalidad y pobreza, como también la capacidad creativa del indígena chaqueño.

\section{Hacia una síntesis del universo de imágenes a través de tres esquemas de percepción del indígena chaqueño}

Las percepciones sobre el indígena chaqueño emanadas de los distintos géneros discursivos analizados a lo largo de casi un siglo pueden ser resumidas atendiendo a tres esquemas interpretativos de la realidad indígena, compuestos por imágenes que respondían tanto a condiciones de producción como de recepción de los mismos. Estos esquemas son: el civilizatorio, el integracionista y el reparacionista-reivindicatorio. Si bien es posible ubicar a cada uno de ellos en períodos de tiempo más o menos delimitados, se producen fisuras con reapariciones de elementos de uno en épocas de supremacía de otro. Por otro lado, la existencia de "imágenes centrales" en estos esquemas de percepción, no implica uniformidad de miradas de las diferentes categorías de observadores, como tampoco coincidencias al interior de la narrativa de un mismo tipo de emisor; por el contrario, en esas imágenes centrales convergen "imágenes periféricas" que en muchas ocasiones revelan miradas contradictorias sobre un mismo aspecto. Ello supone la coexistencia de "varios otros" que se distinguen claramente un "nosotros". 


\section{Las imágenes del esquema civilizatorio}

El esquema civilizatorio se ubica temporalmente antes y durante las campañas militares al Chaco, es decir, desde la organización nacional simbolizada en la Constitución Nacional de 1853 hasta la finalización de las campañas de pacificación en la década del '10 del siglo XX. Este esquema se basa en la superioridad de la cultura del blanco sobre la del "otro" indígena. En correspondencia con el mismo, los distintos discursos de la época crearon la imagen central del indio infiel/salvaje/bárbaro, la que se trasladaba a su vez a una autoimagen del blanco cristiano/civilizado. Esta visión se correspondía con la imagen del Chaco como el "desierto", hábitat del salvaje, que podría convertirse en la "tierra prometida" merced al aporte civilizatorio que el Estado o la Iglesia debían llevar adelante y a la llegada del inmigrante europeo.

Los componentes principales de la imagen del indio infiel eran la pobreza espiritual y material manifiestas en el nomadismo, la alimentación obtenida por la caza y la recolección, la poligamia, el robo, el malón, la embriaguez, la superstición, la holgazanería. El esquema civilizatorio que creó esta imagen, debía a su vez revertirla con acciones concretas orientadas a dos aspectos principales: la sedentarización y el trabajo de la tierra.

La creación de misiones religiosas y las campañas militares fueron dos manifestaciones concretas de imposición del esquema civilizatorio, que compartían el fin, pero se diferenciaron en sus medios: la misión y las armas. La imagen del "buen salvaje"se reflejó en el discurso misionero y en el discurso fotográfico emanado principalmente de fotógrafos profesionales; si bien éstos últimos no se proponían llevar los presupuestos del esquema civilizatorio al ámbito de la acción, sustentaban su discurso en la distinción decimonónica civilización/barbarie y la supremacía de la primera sobre la segunda. Sin embargo, esta imagen vio en el "salvajismo" indígena el elemento exótico donde ciertos ingredientes del primitivismo se convertían en un valor a imitar más que a erradicar o destruir.

Desde el Estado, el sometimiento armado era el paso previo y necesario para imponer el esquema civilizatorio; a partir de los discursos oficiales, "salvaje" y "desierto" eran las imágenes-símbolos del Chaco, que el Estado nacional intentó imponer en la sociedad para justificar su intervención, apoyándose en argumentos científicos que la ciencia positivista y el evolucionismo sustentaron. El periodismo de la época aceptó estas imágenes como así también la acción militar, que se suponía era la solución defi- 
nitiva para someter al "salvaje", pero cuestionó este último cuando hubo que costear nuevas campañas. Es decir, el periodismo metropolitano no impugnaba los presupuestos del esquema civilizatorio, pero esperaba resultados rápidos y eficaces tanto de la labor religiosa como del sometimiento armado.

La imagen del salvaje y bárbaro, central en el imaginario de esta época, permaneció durante gran parte del siglo XX, en especial vinculada a las costumbres y la ociosidad. La percepción del "indio amenaza" que conformaba esa imagen central, pareció tener su fin con las campañas de pacificación concluidas en 1912 por el coronel Rostagno, concordante con el éxito obtenido. Sin embargo, en el discurso de pobladores y de algunos órganos periodísticos chaqueños reaparecía ocasionalmente y se hizo central en la época de la Sublevación de Napalpí en 1924. Parte del periodismo y del discurso oficial territoriano y nacional hicieron reaparecer a través de Napalpí la imagen del malón, que otra parte de la opinión territoriana cuestionó e intentó revertir a través de la imagen del "indio víctima". Con la primera percepción reaparecía implícitamente la distinción entre lo "propio" y lo "ajeno", además de reflejar las limitaciones del otro esquema de percepción, el integracionista. Varios "otros" en un mismo contexto histórico surgen de estas imágenes contrapuestas.

\section{Las imágenes del esquema integracionista}

Promediando la década de 1910, nos encontramos en un momento en que el Estado debió reformular su rol respecto a la problemática indígena: el éxito de las campañas militares, la ocupación progresiva del espacio chaqueño con la extensión de vías férreas y la llegada de inmigrantes, hacía necesaria una actitud diferente frente al "otro". Ésta se desprendió del planteamiento de un esquema integracionista, que continuaba presuponiendo la validez del esquema anterior, el civilizatorio, pero cambió sus argumentos y su accionar en función de las nuevas circunstancias socio-históricas.

En el esquema integracionista el concepto "sometimiento" es reemplazado por "integración", el que ya había sido utilizado por algunos misioneros en el siglo XIX. El "desierto" chaqueño se había convertido en la "tierra de progreso" merced a la labor del colono inmigrante, y por lo tanto todo resabio de primitivismo debía ser extirpado. Sólo algunos vieron en el indígena un "elemento" que también había colaborado en el "progreso" 
por considerarlo la mano de obra óptima (aunque en realidad era la más barata) y fueron aún menos los que advirtieron la pérdida progresiva de las costumbres, como fue el caso del funcionario Elías Niklison.

Se sustentó la imagen central del "pobre indio desposeído y explotado" y la del "indio menor de edad e indefenso". El indígena pasó a ser el desposeído que había que integrar a través de la tierra, el trabajo y para unos pocos, por medio de la educación. Las reducciones civiles creadas al iniciarse la segunda década del siglo XX (Napalpí en el Chaco y Bartolomé de las Casas en Formosa) se erigieron en la puesta en práctica de un sistema integracionista que lograría ligar el indio a la tierra, enseñarle a que la cultive, y educaría a sus hijos haciendo hincapié en una formación técnica orientada a las labores agrícolas, ganaderas y a diferentes oficios. Estos eran los mismos presupuestos del esquema civilizatorio del siglo XIX que se incluían en el integracionista.

El concepto de "desposeído" fue vinculado especialmente al tema de la tierra: en oposición a esta imagen, aparecía la del "colono blanco propietario", que en algunos casos también representaba el "explotador" del indio trabajador. La integración a través de la tierra y del trabajo creó imágenes contradictorias que respondían a los intereses de los interlocutores - algunas de las cuales permanecen hasta la actualidad-: muchas de las propuestas estatales de integración a través de la adjudicación de tierras con la creación de colonias o reservas nunca se hicieron efectivas y aquellas que intentaron ponerse en práctica chocaron con los intereses de pobladores blancos.

Por otro lado, la imagen del "indio menor de edad e indefenso" tenía como contrapartida la autoimagen del "blanco competente y protector". Esta visión se sustentó en la incapacidad de manejarse por sí solo según las normas de la cultura occidental, en la ignorancia de esas normas y en la capacidad intelectual limitada que se afirmaba tenía el indígena. Por estas razones, y porque los enfrentamientos entre pobladores blancos e indios se hacían cada vez más frecuentes, los distintos discursos de la época supusieron la obligación del Estado de proteger al indígena chaqueño. La visión emanada de las normas legales metropolitanas manifestaba una intención proteccionista, pero continuó construyéndose en torno a la antinomia civilización/barbarie. La política proteccionista partía de la convicción implícita de la superioridad del blanco para programar y dirigir la vida del indígena, con la justificación explícita de integrarlo a las normas de una sociedad que le otorgaría un bienestar. 
Los logros del esquema integracionista se pusieron de manifiesto tanto en el discurso escrito como visual de textos gubernativos y periodísticos, y fueron simbolizados en la reducción de Napalpí. La fotografía colaboró en la conformación de la imagen integradora del indígena, que iba adecuándose progresivamente a la "sociedad civilizada", viviendo en la Reducción, trabajando en la explotación forestal, en la agricultura, enviando a sus hijos a la escuela y, por consiguiente, perdiendo sus pautas culturales y asimilando las del blanco.

Las artes plásticas, sin embargo, representaron una actitud más crítica a la concepción integracionista: dejaron entrever los costos del sometimiento y la integración a través de la imagen del indio vencido y postergado o bien aquella iconografía que simboliza los escasos elementos propios que conservaba la cultura indígena.

Napalpí se había convertido en el símbolo del esquema integracionista, pero también marcó los límites del mismo. La sublevación o concentración que ocurrió en 1924 en esa reducción constituyó un punto de inflexión en la imagen del indio chaqueño, especialmente en el discurso periodístico: durante los sucesos, el periodismo se dividió entre aquellos que hicieron reaparecer la imagen del "malón" propia del imaginario civilizatorio, y los que se volcaron a acentuar la imagen del "pobre indio explotado y marginado". Napalpí contribuyó a consolidar esta última visión, que se irá acentuando hasta conformarse en la imagen del "indio víctima" utilizada en el esquema reparacionista-reivindicatorio.

\section{Las imágenes del esquema reparacionista-reivindicatorio}

Hacia la década del ' 40 es posible advertir con mayor fuerza la presencia de un nuevo esquema de percepción de la realidad del indígena chaqueño: el reparacionista-reivindicatorio, que había tenido algunos antecedentes en décadas anteriores. Este esquema consolidó la imagen del "indio víctima" en oposición al "blanco victimario": desde esta visión, el blanco había sido el invasor que despojó al indio de sus tierras, parangonando el imaginario colonial de vencedores/vencidos. Implícitamente se observa una alteración de posiciones respecto a la situación que ocupaban en las imágenes del esquema civilizatorio, donde el blanco era la víctima del malón.

La usurpación realizada por el blanco se convertía en una "deuda histórica"; había que resarcir el daño realizado y la tierra fue el elemento más 
sobresaliente para lograr la reparación a quien se nominaba como un "paria en su propia tierra". Se insistió desde distintos sectores en la entrega de tierras, en especial a través de títulos precarios de ocupación comunal o individual, pero las 150.000 hectáreas que conformaban la reserva del río Teuco desde 1924 nunca fueron entregadas.

Al mismo tiempo que se exclamaba la necesidad de entregar tierras, el sentimiento de culpa emanado de la visión del "indio víctima" estimuló medidas asistencialistas tanto por parte del Estado paternalista como de distintas asociaciones benéficas y religiosas. La entrega de tierras debía ir acompañada por la provisión de herramientas y proveedurías: además de "dar al otro lo que le corresponde", es decir la tierra, se proponía asegurar su bienestar a través de actos de beneficencia, aspectos que la fotografía de pobladores, periodistas y funcionarios se ocupó de documentar.

La posición reparacionista, que posteriormente se reformuló en la reivindicatoria, no excluyó la necesidad de "integrar" al "indio víctima"; es decir, la forma de vida del victimario continuaba siendo la correcta y la que se esperaba que finalmente el otro adoptara. Hacia fines de la década del '50 continuaban reapareciendo las bases del esquema civilizatorio: incorporar al indio a la civilización a través de su sedentarización y el trabajo metódico.

El pensamiento reivindicatorio, si bien fue utilizado principalmente por los representantes del indigenismo chaqueño, no fue privativo de éstos y su influencia se hizo notar en distintos ámbitos de la vida chaqueña. Esta corriente elevó la imagen del "indio víctima" a un drama social: apelaba a refrescar la memoria sobre las relaciones entre blancos e indios en el Chaco y consideraba que para la solución de ese drama no bastaba la entrega de tierras. La problemática debía ser considerada desde una perspectiva integral, atendiendo a la tierra, el trabajo, la salud pero principalmente la educación y el reconocimiento de la cultura del "otro". A la vez se veía necesaria la aculturación que llevara a asegurarles los "beneficios del progreso", presupuestos del esquema civilizatorio de un siglo atrás.

Este esquema reparacionista-reivindicatorio mostraba al indio contemporáneo como el "paria" pero también como el símbolo de "lo autóctono", "lo propio", llegando en algunos casos - como en las posturas indigenistas más radicales-, a una idealización de lo indígena. El arte chaqueño también se orientó a rescatar la figura del indio como lo autóctono, ya sea acudiendo a imágenes ideales de un pasado mítico y glorioso como a retratos que simbolizaban la esencia de una raza. Ciertas costumbres indígenas 
fueron resaltadas por las artes plásticas para aludir a la identidad de una raza que en la realidad ya había perdido muchos de los hábitos, tradiciones y prácticas que se representaban.

Este esquema intentó reunificar una identidad perdida, mostrando, ensalzando o idealizando "lo indio"; pero subsistía la concepción del "otro distinto", basado en una "diferencia cultural legítima" que remarcaba la superioridad de la cultura del blanco respecto de la indígena, concretada en la praxis social, religiosa, legal, cultural e institucional.

$\mathrm{El}$ indigenismo reivindicatorio intentó romper con la imagen genérica del indio chaqueño, diferenciando los intereses, las necesidades, las costumbres, etc. de las distintas etnias. Sin embargo, cuando estas acciones fueron tomadas desde el plano político, se perdieron los perfiles diferenciales y se reunificó la imagen "visto un indio, vistos todos".

Arribando a fines de la década del sesenta, el imaginario sobre el indio chaqueño se componía de imágenes contradictorias y ambivalentes, que reflejaban un problema inconcluso. Se continuaba argumentando la necesidad de "civilizar", no al "buen salvaje" o "feroz salvaje" que conformaba las visiones del siglo XIX, sino a la "pobre víctima" del accionar del blanco. Es evidente que las representaciones focalizadas en el "otro" se fundamentaban en la necesidad del blanco de purgar culpas históricas.

Este itinerario de imágenes de la alteridad, donde el "salvaje" e "infiel" pasa luego a ser el "desposeído" y "explotado", el "paria" y "víctima", supone un "nosotros" portador del cambio para hacerlos parecidos a sí mismos, o utilizarlos como mano de obra para beneficio propio, o protegerlos por ser "menores indefensos". De estas imágenes se deduce, asimismo, la existencia de "varios otros" en diferentes momentos del devenir histórico, pero también en un mismo escenario espacio-temporal: la coexistencia de imágenes opuestas, que respondían a intereses e ideologías de los diferentes grupos sociales, es una característica del imaginario de la alteridad indígena chaqueña que perdura hasta la actualidad. 